Bangladesh Rice J. 20 (1) : 65-75, 2016

\title{
Fertilizer and Weed Management Options for Direct Wet Seeded Rice in Dry Season
}

\author{
R Shultana ${ }^{*}$, J C Biswas ${ }^{1}$, M A A Mamun ${ }^{2}$ and L Nahar ${ }^{1}$
}

\begin{abstract}
Direct seeding of rice is an emerging technology. However, direct seeded rice culture in the main field is hindered by enormous weed infestation and it lacks judicious fertilizer management. So, experiments were conducted during dry seasons of 2010 and 2012 with three fertilizer packages and four weed control measures. Rice seed was sown in the field using drum seeder in wet soil. The results revealed that weed density and weed biomass were strongly influenced by weed control methods and fertilizer rates. Weed density was higher in unweeded plots with 140:36:43 $\mathrm{kg}^{\text {NPK ha-1 }}{ }^{-1}$. Among the species Echinichloa crusgalli (L.) P. Beauv. was the dominant species. Three hand weeding controlled maximum weeds. Uses of herbicide for controlling weeds were above 80 and $70 \%$ effective. Strong negative correlation was recorded between grain yield and weed density. Herbicide with one hand weeding and BRRI weeder in combination with 160:46:53 kg NPK ha-1 produced about $81-104 \%$ higher grain yield than no weeding. Weed free plot produced 112\% higher yield with 160:46:53 kg NPK ha-1. Besides, herbicide with one hand weeding and BRRI weeder treated plot produced similar yield irrespective of fertilizer doses. The strong positive and linear relationship was found in case of yield and yield components. Herbicide with one hand weeding and 120:26:33 kg NPK ha-1 gave higher net return (1145 \$/ha). The benefit cost ratio was also higher in herbicide based weed management with reduced rate of fertilizer. Direct seeded culture using herbicide with one hand weeding and 120:26:33 $\mathrm{kg} \mathrm{NPK} \mathrm{ha-1}$ could be an option for reducing production cost in dry season along with satisfactory grain yield.
\end{abstract}

Key words: Direct seeding, Boro rice, weed, fertilizer, benefit cost ratio

\section{INTRODUCTION}

Traditionally, rice is grown through transplanting on puddle soil, which needs huge labour as well as water. To combat with this situation, growers in many Asian countries shifting their production system from traditional puddle transplanted rice to direct seeded culture. Direct seeded rice (DSR) is less labour intensive, consumes less water, crop matures 7 to 10 days earlier than traditional transplanted rice. But, DSR faces multiple problems during its growth and development processes from sowing to maturity. Inconsistent plant population, injudicious use of fertilizer, water stress or presence of weeds in the field often limit crop yield of DSR. Among the crop production constraints, judicial use of fertilizer and economic weed management are very important. The risk of yield loss from weeds in DSR is greater than transplanted culture (Rao et al., 2007).

Grain yield reduction in DSR could be 3591\% depending on water and fertilizer management (Sunil et al., 2010). However, different weed control options are available in rice production. Physical control are ecofriendly but labour-intensive (Roder and Keobulapha, 1997). Delayed weeding due to unavailability of labour is another constraint of physical control (Johnson, 1996). Biological

${ }^{1}$ Bangladesh Rice Research Institute (BRRI), Gazipur; ${ }^{2}$ Bangabandhu Sheikh Mujibur Rahman Agricultural University, Gazipur, Bangladesh. *Corresponding author's E-mail : rakiba_83@yahoo.com 
control by using different bio-agents (Smith, 1992) and mycoherbicides (Thi et al., 1999) may not be effective under aerobic soil conditions. Worldwide Chemical control measures are becoming popular day by day. Many researchers working on weed management in direct seeded rice opined that herbicide may be considered to be a viable alternative to hand weeding (Anwar et al., 2012). However, single weed control approach may not be able to keep weeds below economic threshold level, and may resulting in weed flora, resistance development and environmental hazards. Therefore, diverse weed management strategies need to be practiced for effective weed management.

Like weed management, imbalanced fertilizer rates cause yield reduction. Improper doses of fertilizer often stimulate higher weed prevalence in rice field. Management of weeds along with balanced fertilizers increased net income by reducing losses due to weeds, increasing fertilizer use efficiency and finally increasing the grain yield (Rana et al., 2000).

Limited information on weed and fertilizer management options with DSR system is available for Asian regions. As DSR is an emerging production system, information on integrated effect of fertilizer and weed management on DSR may be helpful to achieve higher yield and to reduce production cost. It is, therefore, a need to explore the efficacy of the methods of weed control and fertilizer rates for augmenting the crop yield. The present study was, therefore, conducted to determine a suitable weed control method and fertilizer management option for obtaining higher grain yield and cost effectiveness under direct wet seeded rice culture.

\section{MATERIALS AND METHODS}

\section{Experimental site}

Two field experiments were conducted at research field of Bangladesh Rice Research Institute, Gazipur (90³3’ E longitude and 23⒎' N latitude), Bangladesh during Boro season (January to May) in 2010 and 2012. The soil of the experimental field belongs to the Shallow Red Brown Terrace Soils. The soil was loamy having 47, 35 and 18\% sand, silt and clay respectively. Initial soil $\mathrm{pH}, 6.13$; organic matter, $1.4 \%$; the total $\mathrm{N}, 0.133 \%$; available $\mathrm{P}, 13.80 \mathrm{mg} \mathrm{g}^{-1}$; exchangeable $\mathrm{K}$, 0.126 meq $100 \mathrm{~g}^{-1}$; available $S, 20.27 \mathrm{mg} \mathrm{g}^{-1}$ and $\mathrm{Zn}$ were, $0.582 \mathrm{mg} \mathrm{g}^{-1}$. The average air temperature $\left({ }^{\circ} \mathrm{C}\right)$ was almost similar during two reported years. However the highest rainfall was recorded in mid April during 2012 (Fig. 1).

\section{Execution of experiments}

The treatments were assigned in a randomized complete block design with factorial arrangement and repeated thrice. Unit plot size was $4.6-\times 3-\mathrm{m}$. Rice varieties BRRI dhan29 and BRRI dhan28 were used as test crops during 2010 and 2012 respectively. The experiment comprised of three fertilizers and four weed management options (Table 1).

The pre-germinated seeds were sown on puddled and leveled soil by drum seeder. The whole $\mathrm{P}$ and $\mathrm{K}$ and one third of $\mathrm{N}$ were applied at final land preperation. The remaining $\mathrm{N}$ was applied in two splits at tillering and panicle initiation equally. Herbicide, Sirius 10WP (pyrazosulfuran ethyl) was applied at 2-3 leaf stage of weed at $150 \mathrm{~g}$ ha $^{-1}$. BRRI developed rice weeder was applied at 20 and 45 DAS. 


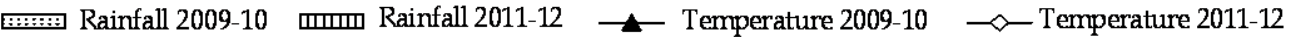

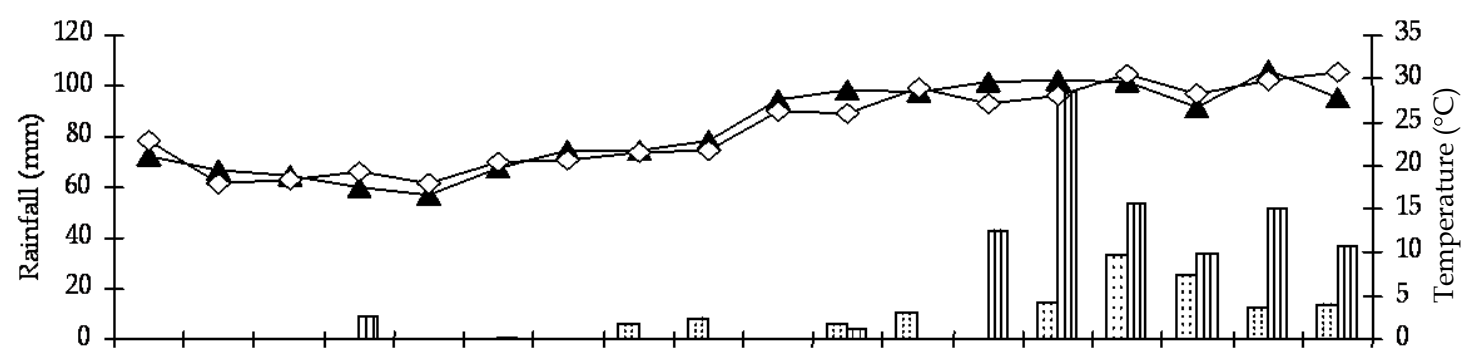

10-Dec 20-Dec 30-Dec 10-Jan 20-Jan 30-Jan 10-Feb 20-Feb 28-Feb 10-Mar 20-Mar 30-Mar 10-Apl 20-Apl 30-Apl 10-May 20-May30-May

Fig. 1. Temperature and rainfall pattern during experimentation, BRRI, Gazipur.

\section{Collection of weed data}

Weed samples were collected at 50 DAS. Plot wise weed species were counted and dry weights were taken after drying in oven (Perkin-Elmer Corporation, USA) at $60^{\circ} \mathrm{C}$ for 72 hours. Weed control efficiency (WCE) was calculated according to Rao (1985).
The contribution of an individual weed species to the weed community were determined by its two factor summed dominance ratio (SDR) (Janiya and Moody, 1989). This was calculated using Relative Weed Density (RWD) and Importance value (IV), as following:

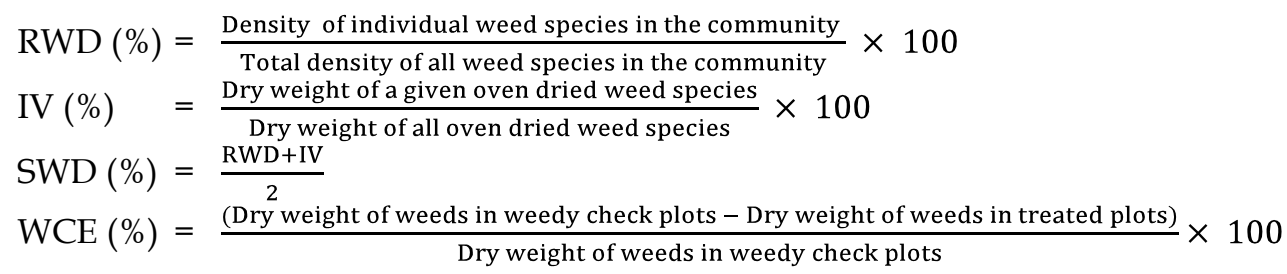

\section{Statistical analysis}

Data were analyzed following analysis of variance (ANOVA) and mean differences were depicted by multiple comparison test (Gomez and Gomez, 1984) using the statistical programme MSTAT-C (Russell 1986).
Gross return, net return and total variable cost were calculated and expressed as dollar (\$) ha $^{-1}$. Net return was calculated by (Gross return - Total variable cost). Benefit cost ratio (BCR) was calculated as:

Benefit cost ratio $(B C R)=\frac{\text { Gross return }}{\text { Total variable cost }}$

\section{Economic analysis}

Table 1. Description of treatments.

\begin{tabular}{lllll}
\hline Factor & Symbol used & \multicolumn{3}{c}{ Level of nutrients $\left(\mathrm{kg} \mathrm{ha}^{-1}\right)$} \\
\cline { 3 - 4 } & & Nitrogen $(\mathrm{N})$ & 26 & Phosphorus $(\mathrm{P})$ \\
\hline Fertilizer & $\mathrm{F}_{1}=120: 26: 33 \mathrm{~kg} \mathrm{NPK} \mathrm{ha}^{-1}$ & 120 & 36 & 33 \\
package & $\mathrm{F}_{2}=140: 36: 43 \mathrm{~kg} \mathrm{NPK} \mathrm{ha}^{-1}$ & 140 & 46 \\
& $\mathrm{~F}_{3}=160: 46: 53 \mathrm{~kg} \mathrm{NPK} \mathrm{ha}^{-1}$ & 160 & 53 \\
& & Description of weeding & \\
Weed & $\mathrm{W}_{1}$ & $\begin{array}{l}\text { Post emergence herbicide (Pyrazosulfuran ethyl)+one hand weeding } \\
\text { control }\end{array}$ & & at 45 days after sowing (DAS) \\
& $\mathrm{W}_{2}$ & Three hand weeding at 20, 35 and 45 DAS \\
& $\mathrm{W}_{3}$ & BRRI weeder at 30 and 45 DAS \\
& $\mathrm{W}_{4}$ & No weeding (control) \\
\hline
\end{tabular}




\section{RESULTS AND DISCUSSION}

\section{Weed vegetation}

The dominant weed species were Echinochloa crusgali (L.), Cynodon dactylon (L.), Scirpus maritimus (L.) and Monochoria vaginalis belonging to family Poaceae, Cyperaceae and Pontederiaceae comprises three major classes Grass, Sedge and Broadleaf.

\section{Weed density and biomass}

In both the years, weed density and weed biomass were higher in no weeding treated plot with 140:36:43 kg NPK ha-1. However, weed free plot with fertilizer doses 120:26:33 $\mathrm{kg}$ NPK ha ${ }^{-1}$ resulted $94.88 \%$ and $93.74 \%$ lower weed density and $97.57 \%$ and $97.99 \%$ lower weed biomass than 140:36:43 kg NPK ha $^{-1}$ treated no weeding plot in 1st and 2 nd year, respectively. The plot received herbicide with one hand weeding and fertilizer doses 120:26:33 kg NPK ha-1 produced $74.56 \%$ and $75.40 \%$ lower weed density and $83.66 \%$ and $86.29 \%$ lower weed biomass in year 1 and year 2 respectively (Fig. 2). BRRI weeder treated plot with fertilizer doses 120:26:33 kg NPK ha ${ }^{-1}$ gave $72.22 \%$ and $75.29 \%$ lower weed density and $79.15 \%$ and $82.92 \%$ lower weed biomass compared to 140:36:43 $\mathrm{kg}^{\text {NPK ha-1 }}$ with no weeding treated plot in year 1 and year 2 respectively (Table 2). Weed density increases with the increased rate of fertilizer application. Weeds have a higher nutrient requirement than crops and compete strongly for nutrients when high fertilizer rates are applied (Burgos et al., 2006; Chauhan and Johnson, 2010a and 2011a). Application of post emergence herbicide with single hand weeding plus minimum rate of fertilizer not only produces lower weed density but also lower weed biomass. This findings is supported by Chauhan and Ope na (2013). They observed that additional yield in herbicide treated plot could be achieved by following one hand weeding after post emergence herbicide application.

Table 2. Interaction effect of fertilizer and weed management on weed density and biomass in direct wet seeded Boro rice 2010 and 2012, BRRI Gazipur.

\begin{tabular}{|c|c|c|c|c|}
\hline \multirow[t]{2}{*}{ Treatment } & \multicolumn{2}{|c|}{ Boro 2010} & \multicolumn{2}{|c|}{ Boro 2012} \\
\hline & Weed no. $/ \mathrm{m}^{2}$ & Weed wt $\left(\mathrm{g} / \mathrm{m}^{2}\right)$ & Weed no. $/ \mathrm{m}^{2}$ & Weed wt $\left(\mathrm{g} / \mathrm{m}^{2}\right)$ \\
\hline & & 120:26:33 NPK kg ha-1 & & \\
\hline Herbicide + 1 HW & 58.00 & 14.81 & 56.67 & 12.47 \\
\hline Weed free & 11.67 & 2.20 & 14.67 & 1.83 \\
\hline BRRI weeder & 63.33 & 18.89 & 56.67 & 15.53 \\
\hline No weeding & 191.997 & 82.01 & 189.00 & 82.50 \\
\hline & & 140:36:43 NPK kg ha-1 & & \\
\hline Herbicide + 1 HW & 70.67 & 19.00 & 66.67 & 16.17 \\
\hline Weed free & 16.00 & 3.40 & 18.00 & 2.80 \\
\hline BRRI weeder & 81.33 & 40.54 & 82.00 & 39.83 \\
\hline No weeding & 228.00 & 90.63 & 229.33 & 90.93 \\
\hline & & 160:46:53 NPK kg ha-1 & & \\
\hline Herbicide + 1 HW & 66.00 & 42.38 & 67.67 & 42.70 \\
\hline Weed free & 13.33 & 2.93 & 16.00 & 2.53 \\
\hline BRRI weeder & 110.77 & 53.49 & 115.00 & 54.43 \\
\hline No weeding & 190.00 & 65.04 & 152.00 & 65.30 \\
\hline CV (\%) & 10.19 & 12.18 & 19.90 & 12.48 \\
\hline $\operatorname{LSD}(0.05 \%)$ & 16.04 & 7.580 & 30.25 & 7.618 \\
\hline
\end{tabular}



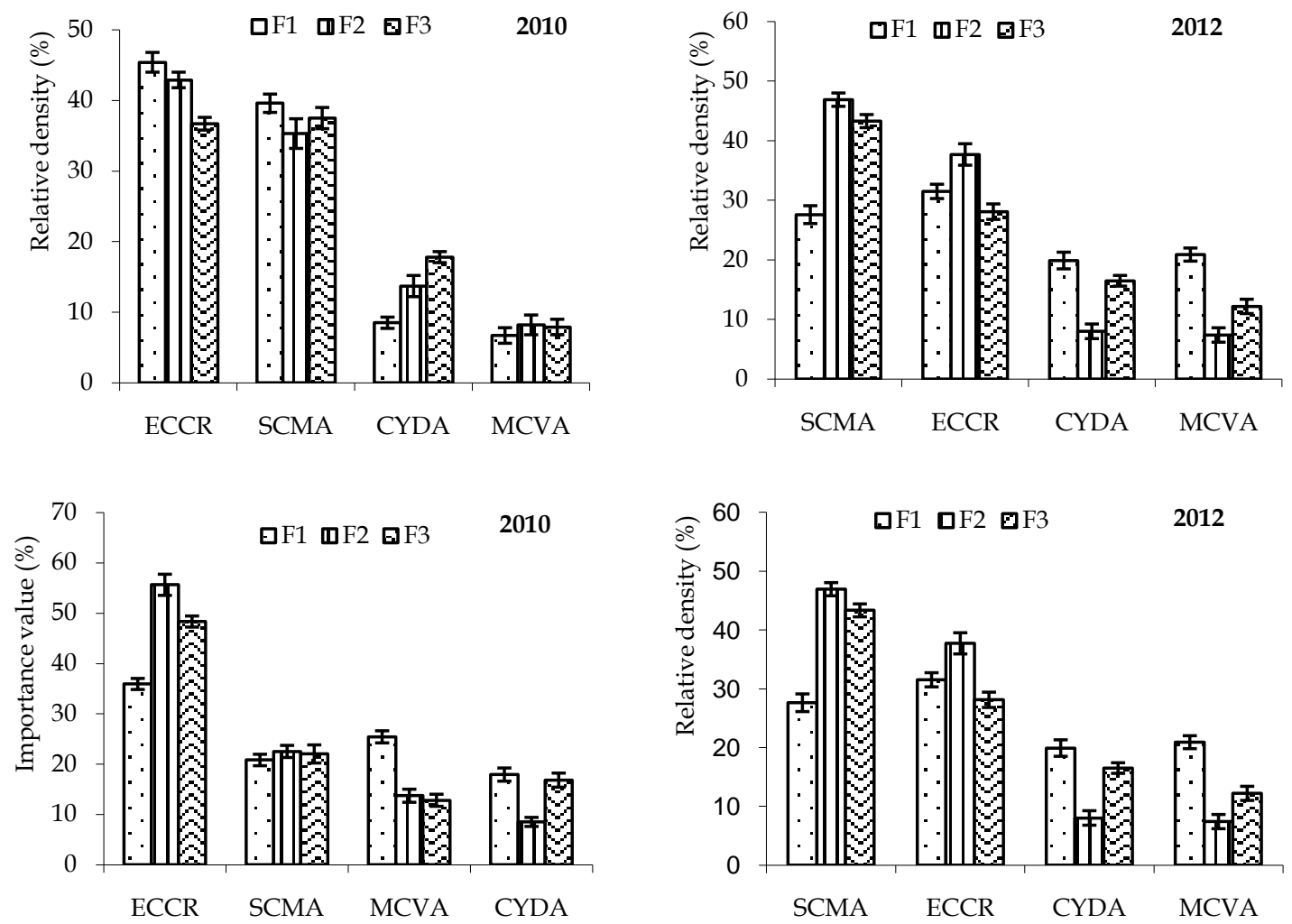

ECCR = Echinochloa crus-galli, SCMA = Scripus maritimus, MCVA = Monochoria vaginalis, CYDA = Cynodon dactylon, $F_{1}=120: 26: 33 \mathrm{~kg} \mathrm{NPK} \mathrm{ha}^{-1}, \mathrm{~F}_{2}=140: 36: 43 \mathrm{~kg} \mathrm{NPK} \mathrm{ha}^{-1}, \mathrm{~F}_{3}=160: 46: 53 \mathrm{~kg} \mathrm{NPK}^{-1}$. The vertical bars represent the standard error.

Fig. 2. Relative density and importance value of different weeds in direct wet seeded Boro rice 2010 and 2012, BRRI, Gazipur.

\section{Relative density (RD) and importance value (IV) of weeds}

Among the infesting weed species E. crusgalli showed maximum relative density with 120:26:33 kg NPK ha-1 (45.4\%) in year 1, while in year $2, S$. maritimus showed maximum relative density with $140: 36: 43 \mathrm{~kg}$ NPK ha-1 (46.9\%). On the other hand E. crusgalli showed higher importance value with 140:36:43 kg NPK ha-1 both in year 1 (55.6\%) and Year 2 (49.7\%). Among the weed species E. crusgalli, recognized as the most devastating weeds for its higher density and importance value.

\section{Weed ranking}

In year 1 , the most dominating weed species was E. crusgalli (40.76-49.05\%). In year 2, E. crusgalli $(43.7 \%)$ and S. maritimus $(43.2 \%)$ were dominating weeds with fertilizer doses 140:36:43 kg NPK ha-1. However, the grasses $(11.08-49.0 \%$ in year 1 and $7.3-43.7 \%$ in year 2) were the most dominating weeds. The weed dominance ranking expressed $E$. crusgalli first in position. It proves that due to low land ecosystem our soil is very much conducive for germination and growth of $E$. crusgalli. Besides, new seed drops to soil surface every year and increases its seed bank. This findings is supported by Mortimer and Riches (2001), Shultana et al. (2011), Al-Mamun et al. (2010) (Fig. 3).

Fertilizer and Weed Management Options for Direct 

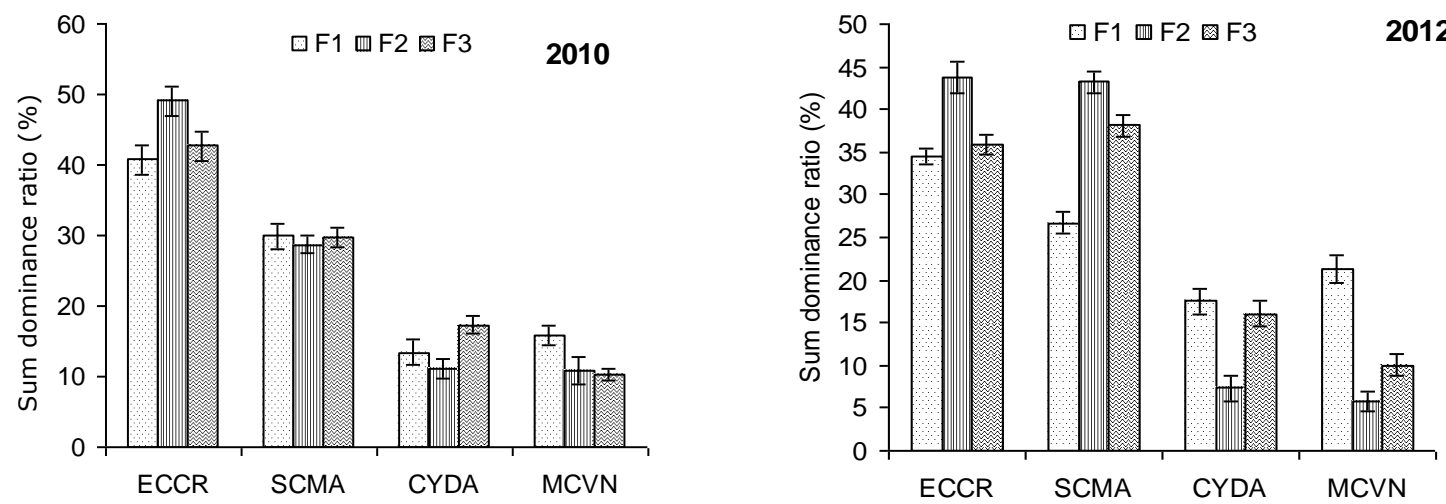

2ECCR $=$ Echinochloa crus-galli, $\mathrm{SCMA}=$ Scripus maritimus, $\mathrm{MCVA}=$ Monochoria vaginalis, $\mathrm{CYDA}=$ Cynodon dactylon, $F_{1}=120: 26: 33 \mathrm{~kg}$ NPK ha-1, $F_{2}=140: 36: 43 \mathrm{~kg}$ NPK ha-1, $F_{3}=160: 46: 53 \mathrm{~kg}$ NPK ha-1. The vertical bars represent the standard error.

Fig. 3. Effect of fertilizer doses on weed dominance ranking in direct wet seeded Boro rice 2010 and 2012, BRRI, Gazipur.

Interaction effect of fertilizer and weeding method on WCE (\%)

In both the years, the weed free plot had higher weed control efficiency than the other weeding methods. In year 1 , the weed free plot with fertilizer doses 160:46:53 kg NPK ha ${ }^{-1}$ had $90.97 \%$ weed control efficiency. In year 2, the weed free plot gave $87.82 \%$ weed control efficiency with fertilizer doses 120:26:33 $\mathrm{kg}$ NPK ha-1. The plot treated with herbicide with one hand weeding gave above $80 \%$ weed control efficiency irrespective of fertilizer dose in year 1 and above $70 \%$ weed control efficiency irrespective of fertilizer dose in year 2. In both the years, BRRI weeder treated plot showed above $60 \%$ weed control efficiency irrespective of fertilizer dose (Table 3).

Relationship of rice yield with weed density (plant $\mathrm{m}^{-2}$ ) and biomass $\left(\mathrm{g} \mathrm{m}^{-2}\right)$

In both the years grain yield showed strong negative relation with weed number and weed biomass. Singh et al. (2008) observed irrespective of the stage of crop growth and type of weed group, a significant negative correlation of weed density and weed dry weight with rice grain and straw yield, indicating the need for minimizing weed density and dry weight to attain optimal rice grain yield (Fig. 4).

Table 3. Interaction effect of different fertilizer rate and weeding options on weed control efficiency (\%) in direct wet seeded Boro rice 2010 and 2012, BRRI, Gazipur.

\begin{tabular}{|c|c|c|c|c|c|c|}
\hline \multirow[t]{2}{*}{ Treatment } & \multicolumn{3}{|c|}{ Boro 2010} & \multicolumn{3}{|c|}{ Boro 2012} \\
\hline & $\begin{array}{c}\text { 120:26:33 } \\
\text { kg NPK ha-1 }\end{array}$ & $\begin{array}{c}\text { 140:36:43 kg } \\
\text { NPK ha-1 }\end{array}$ & $\begin{array}{c}\text { 160:46:53 kg } \\
\text { NPK ha-1 }\end{array}$ & $\begin{array}{c}\text { 120:26:33 kg } \\
\text { NPK ha-1 }\end{array}$ & $\begin{array}{c}\text { 140:36:43 kg } \\
\text { NPK ha-1 }\end{array}$ & $\begin{array}{c}\text { 160:46:53 } \\
\text { kg NPK } \\
\text { ha }^{-1}\end{array}$ \\
\hline $\begin{array}{l}\text { Herbicide+one } \\
\text { hand weeding }\end{array}$ & 81.72 & 80.26 & 80.41 & 80.40 & 77.88 & 71.25 \\
\hline Weed free & 90.25 & 91.28 & 90.97 & 87.82 & 85.71 & 82.51 \\
\hline BRRI weeder & 73.04 & 74.70 & 68.86 & 67.32 & 66.63 & 67.83 \\
\hline No weeding & - & - & - & - & - & - \\
\hline
\end{tabular}



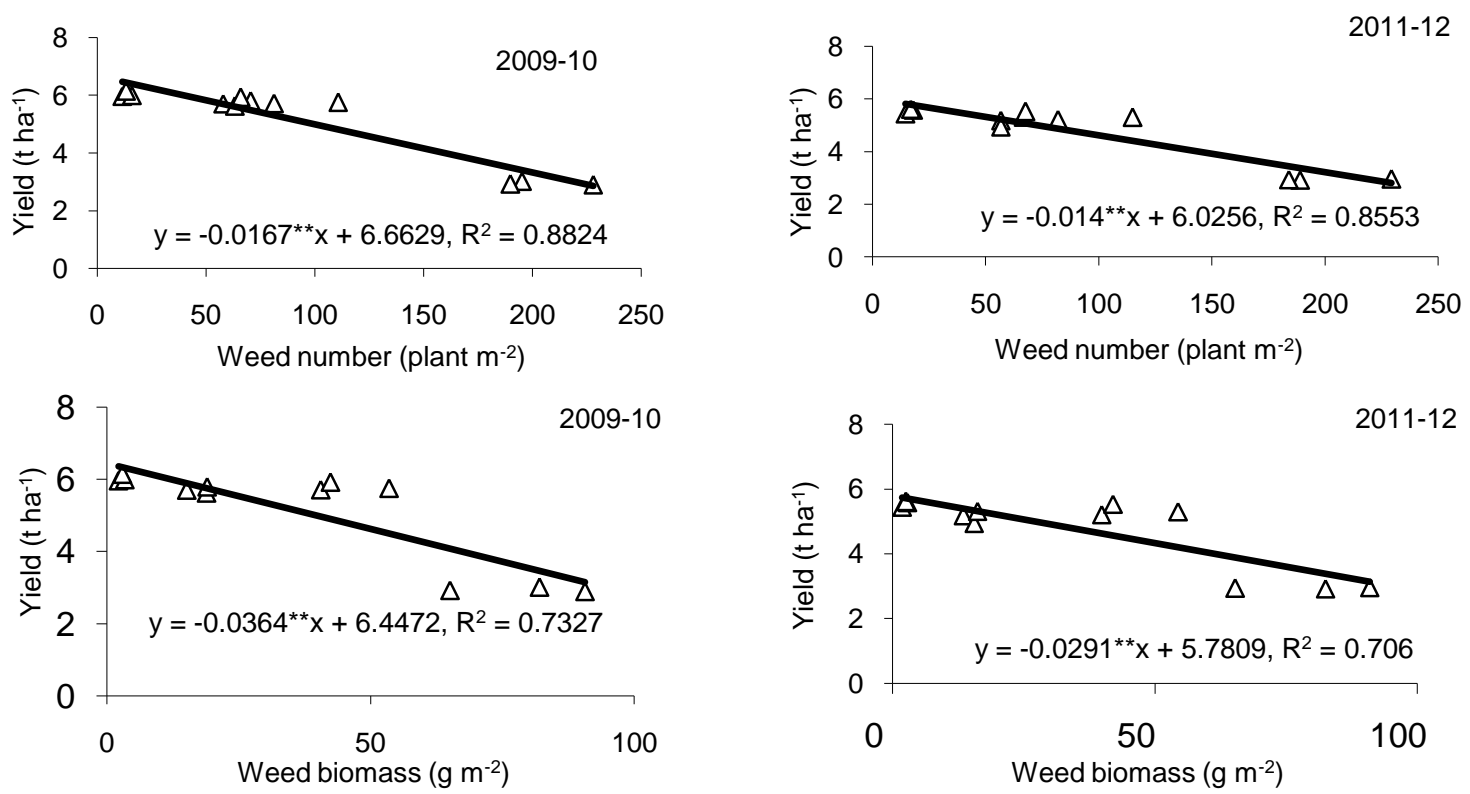

Fig. 4. Relationship of rice yield with weed density (plant $\left.\mathrm{m}^{-2}\right)$ and biomass $\left(\mathrm{g} \mathrm{m}^{-2}\right)$ in Boro season during 2010 and 2012.

Interaction effect of fertilizer and weeding options on yield contributing characters

In both the years, insignificant interaction effect was found in case of panicle $\mathrm{m}^{-2}$. Although grains panicle ${ }^{-1}$ was significant in year 1, insignificant interaction effect was observed in year 2. Thousand-grain weight (TGW) varied significantly both in year 1 and year 2. In year 1, significantly higher grain panicle $^{-1}$ were found in weed free treatment with 140:36:43 kg NPK ha-1 (85) and 160:46:53 kg NPK ha-1 (85), which was statistically similar to herbicide + $1 \mathrm{HW}$ with $140: 36: 43 \mathrm{~kg}$ NPK ha-1 (83). The lowest grain panicle-1 was recorded in no weeding plot with $120: 26: 33 \mathrm{~kg}$ NPK ha-1 (43). However, in year 2, treatment effect was insignificant. The highest TGW in year 1 was recorded in weed free treatment with 120:26:33 kg NPK ha-1 (20.10g) which was statistically similar to weed free with 140:36:43 kg NPK ha-1 (20.02g), 160:46:53 kg NPK ha-1 (20.07) and herbicide plus one hand weeding with 120:26:33 kg NPK ha-1 (20.08g) treatment and the lowest was found in no weeding with fertilizer doses 160:46:53 kg
NPK ha-1 (18.08g). In year 2 , the highest TGW was found in herbicide $+1 \mathrm{HW}$ with fertilizer doses 160:46:53 kg NPK ha-1 (21.47). In year 1, weed free plot with 160:46:53 kg NPK ha-1 produced significantly higher yield, which was $112 \%$ higher than 140:36:43 kg NPK ha-1 with no weeding plot.

The plot received herbicide with one hand weeding and BRRI weeder were statistically similar irrespective of fertilizer rate. The plot treated with 160:46:53 kg NPK ha $^{-1}$ and herbicide with one hand weeding and BRRI weeder with same fertilizer dose produced $104.45 \%$ and $98.62 \%$ higher than no weeding plot with 140:36:43 $\mathrm{kg} \mathrm{NPK} \mathrm{ha}^{-1}$. In year 2, weed free with 160:46:53 kg NPK ha-1 produced significantly higher yield, which was statistically similar to weed free with 120:26:33 kg NPK ha-1 and 140:36:43 kg NPK ha $^{-1}$ and shows $92.12 \%$ higher yield than 120:26:33 kg NPK ha-1 treated with no weeding plot. However, herbicide with one hand weeding and BRRI weeder treated plot gave higher yield with 160:46:53 kg NPK ha $^{-1}$. This is $89.38 \%$ and $81.51 \%$ higher than

Fertilizer and Weed Management Options for Direct 71 
120:26:33 kg NPK ha-1 with no weeding plot (Table 4). Significant interaction effect of fertilizer and weeding method on grain yield was observed in both the years. Among the treatment combination no weeding plot with higher rate of fertilizer produced significantly lower yield. It reveals that higher doses of fertilizer enhanced higher weed pressure. However, weed free plot, herbicide with one hand weeding and BRRI weeder treated plot produced statistically similar yield irrespective of fertilizer dose. Two times application of BRRI weeder resulted lower weed biomass. Due to lower rice weed competition, the maximum fertilizer effect was exhibited on herbicide based weed management and BRRI weeder treated plot. Weed prevalence was comparatively lower where the plot treated with post emergence herbicide at 1-2 leaf stages of weed with additional one hand weeding (43 DAS). Increased $\mathrm{N}$ dose for yield maximization was reported by Singh and Prasad (1999). These results were also supported by Kamara et al. (2011) and Oikeh et al. (2008). They reported that number of grains panicle-1 increased with increased in $\mathrm{N}$ rates and also found number of grains panicle ${ }^{-1}$ was positively correlated with grain yield and subsequently produced higher grain yields of NERICA 1 rice. Increase in grain yield for application of $\mathrm{N}$ was mainly due to improvement in yield components i.e. number of effective tillers and grains panicle ${ }^{1}$.

Relationship between yield and yield components

Based on two years data, yield showed significantly strong positive correlation with yield components. (Fig. 5).

Table 4. Interaction effect of fertilizer and weeding options on yield and yield components in direct wet seeded Boro rice 2010 and 2012, BRRI, Gazipur.

\begin{tabular}{|c|c|c|c|c|c|c|c|c|c|c|c|c|}
\hline \multirow{2}{*}{$\begin{array}{l}\text { Weeding } \\
\text { option }\end{array}$} & \multicolumn{3}{|c|}{ Panicle $\mathrm{m}^{-2}$} & \multicolumn{3}{|c|}{ Grain panicle-1 } & \multicolumn{3}{|c|}{ TWG (g) } & \multicolumn{3}{|c|}{ Yield $\left(t \mathrm{ha}^{-1}\right)$} \\
\hline & $\mathrm{F}_{1}$ & $\mathrm{~F}_{2}$ & $\mathrm{~F}_{3}$ & $\mathrm{~F}_{1}$ & $\mathrm{~F}_{2}$ & $\mathrm{~F}_{3}$ & $\mathrm{~F}$ & $\mathrm{~F}_{2}$ & $\mathrm{~F}_{3}$ & $\mathrm{~F}_{1}$ & $\mathrm{~F}_{2}$ & $\mathrm{~F}_{3}$ \\
\hline \multicolumn{13}{|c|}{ Boro 2010} \\
\hline $\mathrm{W}_{1}$ & 370 & 367 & 374 & 77 & 83 & 84 & 20.08 & 19.83 & 19.61 & 5.71 & 5.8 & 5.93 \\
\hline $\mathrm{W}_{2}$ & 375 & 377 & 372 & 83 & 85 & 85 & 20.10 & 20.02 & 20.07 & 5.97 & 6 & 6.15 \\
\hline $\mathrm{W}_{3}$ & 360 & 366 & 367 & 72 & 80 & 82 & 18.92 & 19.10 & 19.11 & 5.63 & 5.72 & 5.76 \\
\hline $\mathrm{W}_{4}$ & 314 & 319 & 315 & 43 & 53 & 68 & 18.63 & 18.72 & 18.08 & 3.02 & 2.9 & 2.93 \\
\hline LSD & & NS & & & 4.95 & & & 0.05 & & & 0.50 & \\
\hline $\mathrm{CV} \%$ & & 10.18 & & & 3.87 & & & 0.38 & & & 9.05 & \\
\hline \multicolumn{13}{|c|}{ Boro 2012} \\
\hline $\mathrm{W}_{1}$ & 365 & 371 & 368 & 72 & 75 & 81 & 21.01 & 21.43 & 21.47 & 5.18 & 5.31 & 5.53 \\
\hline $\mathrm{W}_{2}$ & 368 & 370 & 377 & 80 & 78 & 77 & 21.04 & 21.10 & 21.13 & 5.44 & 5.58 & 5.61 \\
\hline $\mathrm{W}_{3}$ & 363 & 364 & 363 & 67 & 75 & 71 & 20.73 & 20.67 & 21.01 & 4.94 & 5.21 & 5.3 \\
\hline $\mathrm{W}_{4}$ & 338 & 335 & 328 & 47 & 59 & 50 & 19.84 & 19.89 & 20.09 & 2.92 & 2.96 & 2.94 \\
\hline LSD & & NS & & & NS & & & 0.42 & & & 0.40 & \\
\hline CV\% & & 8.04 & & & 6.73 & & & 1.19 & & & 5.03 & \\
\hline
\end{tabular}

$\mathrm{F}_{1}=120: 26: 33 \mathrm{~kg} \mathrm{NPK} \mathrm{ha}^{-1}, \mathrm{~F}_{2}=140: 36: 43 \mathrm{~kg} \mathrm{NPK} \mathrm{ha}^{-1}, \mathrm{~F}_{3}=160: 46: 53 \mathrm{~kg} \mathrm{NPK} \mathrm{ha}^{-1}, \mathrm{~W}_{1}=$ Herbicide+ $1 \mathrm{HW}, \mathrm{W}_{2}=$ Weed free, $\mathrm{W}_{3}=$ BRRI weeder, $\mathrm{W}_{4}=$ No weeding. 

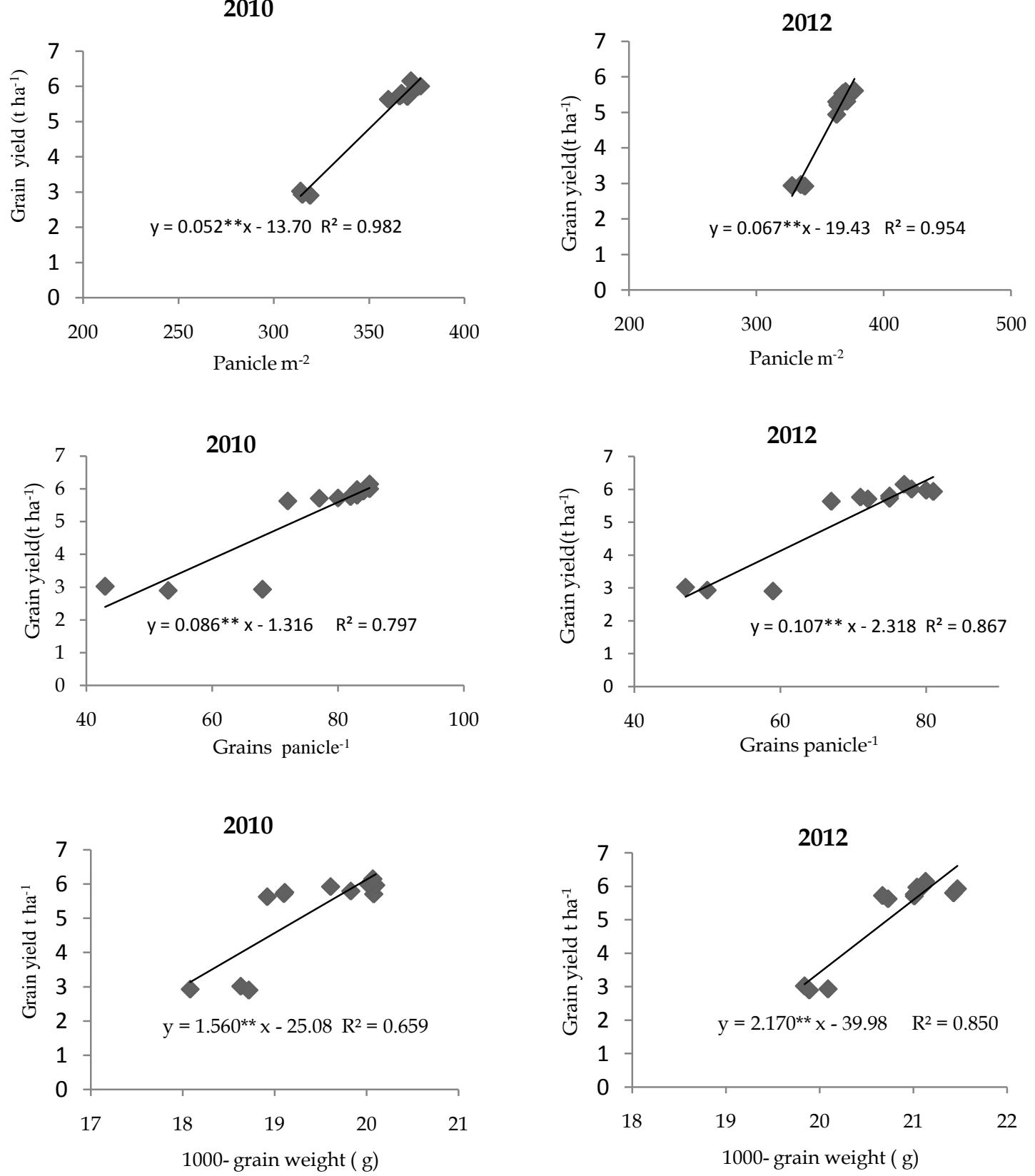

Fig. 5. Relationship of rice yield with panicle $\mathrm{m}^{-2}$, grains panicle ${ }^{-1}$ and 1000-grain weight in Boro season during 2010 and 2012.

Interaction effect of fertilizer and weeding options on economic performance In year 1 , higher gross return $\left(1419.23 \$ \mathrm{ha}^{-1}\right)$ was found in weed free plot with fertilizer doses 160:46:53 $\mathrm{kg}$ NPK ha-1 but the total variable cost was higher with this combination (362.21 $\$$ ha $\left.^{-1}\right)$. Although the 
gross return was higher, it requires higher labour. Due to higher labour price and fertilizer cost the total variable cost increases. Higher net return was found in herbicide with one hand weeding with 120:26:33 kg NPK ha-1 $(1,145.004$ \$/ha). Higher BCR (6.63) was found in herbicide plus one hand weeding with 120:26:33 kg NPK ha-1. In year 2, higher gross return (1,295 \$/ha) was found in weed free with 160:46:53 $\mathrm{kg}$ NPK ha-1. Total variable cost was higher in weed free with 160:46:53 kg NPK ha-1362 \$/ha). However, higher BCR (6.63) was found in herbicide plus one hand

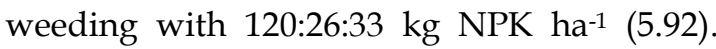
Because herbicide based weed management requires less labour and less cost was involved due to reduced rate of fertilizer. The weed control by mechanical means (BRRI weeder two times) requires higher labour and it also failed to control weeds in between 2 hills. In consequence, the net return was low in BRRI weeder treatment, irrespective of fertilizer dose. (Table 5). These findings are supported by Khaliq et al. (2012) who stated that post emergence herbicide application appeared to be a viable strategy for weed control in direct seeded rice with higher economic returns.

\section{CONCLUSION}

The labour scarcity and fertilizer costs are increasing day by day. For profitable rice farming, reduction of production cost is very important. Direct were seeding of rice may reduce the production cost. Economically viable and satisfactory Boro rice yield under direct seeded culture could be obtained through herbicide use along with one hand weeding applying at 120:26:33 kg NPK ha-1.

Table 5. Economic performance of fertilizer and weeding options in direct wet seeded boro rice, 2010 and 2012, BRRI, Gazipur.

\begin{tabular}{|c|c|c|c|c|c|c|c|c|c|c|c|c|}
\hline \multirow[t]{2}{*}{ Treatment } & \multicolumn{3}{|c|}{$\begin{array}{c}\text { Gross return } \\
\left(\$ \text { ha }^{-1}\right)\end{array}$} & \multicolumn{3}{|c|}{$\begin{array}{c}\text { Variable cost } \\
\left(\$ \text { ha }^{-1}\right)\end{array}$} & \multicolumn{3}{|c|}{$\begin{array}{c}\text { Net return } \\
\left(\$ \text { ha }^{-1}\right)\end{array}$} & \multicolumn{3}{|c|}{ BCR } \\
\hline & $\mathrm{F}_{1}$ & $F_{2}$ & $F_{3}$ & $\mathrm{~F}_{1}$ & $\mathrm{~F}_{2}$ & $F_{3}$ & $\mathrm{~F}_{1}$ & $\mathrm{~F}_{2}$ & $F_{3}$ & $F_{1}$ & $\mathrm{~F}_{2}$ & $\mathrm{~F}_{3}$ \\
\hline \multicolumn{13}{|c|}{ Boro 2010} \\
\hline $\mathrm{W}_{1}$ & 1318 & 1339 & 1369 & 173 & 201 & 229 & 1145 & 1138 & 1139 & 6.63 & 5.66 & 4.97 \\
\hline $\mathrm{W}_{2}$ & 1378 & 1385 & 1419 & 306 & 334 & 362 & 1072 & 1051 & 1057 & 3.51 & 3.15 & 2.92 \\
\hline $\mathrm{W}_{3}$ & 1299 & 1320 & 1329 & 229 & 257 & 285 & 1070 & 1063 & 1044 & 4.68 & 4.13 & 3.66 \\
\hline $\mathrm{W}_{4}$ & 697 & 669 & 676 & 344 & 257 & 285 & 353 & 412 & 391 & 1.02 & 1.60 & 1.37 \\
\hline \multicolumn{13}{|c|}{ Boro 2012} \\
\hline $\mathrm{W}_{1}$ & 1195 & 1225 & 1276 & 173 & 201 & 229 & 1023 & 1024 & 1047 & 5.92 & 5.10 & 4.57 \\
\hline $\mathrm{W}_{2}$ & 1255 & 1288 & 1295 & 306 & 334 & 362 & 950 & 954 & 932 & 3.11 & 2.86 & 2.57 \\
\hline $\mathrm{W}_{3}$ & 1140 & 1202 & 1223 & 229 & 257 & 285 & 911 & 945 & 938 & 3.98 & 3.68 & 3.29 \\
\hline $\mathrm{W}_{4}$ & 674 & 683 & 678 & 344 & 257 & 285 & 329 & 426 & 393 & 0.96 & 1.66 & 1.38 \\
\hline
\end{tabular}

*Only fertilizer and weeding costs were considered, Labour and material costs were considered based on the price of the reported year. $F_{1}=120: 26: 33 \mathrm{~kg} \mathrm{NPK} \mathrm{ha}^{-1}, F_{2}=140: 36: 43 \mathrm{~kg} \mathrm{NPK} \mathrm{ha}^{-1}, \mathrm{~F}_{3}=160: 46: 53 \mathrm{~kg} \mathrm{NPK} \mathrm{ha}^{-1}, \mathrm{~W}_{1}=$ Herbicide $+1 \mathrm{HW}$ at 45 DAS, $\mathrm{W}_{2}=$ Weed free at 20, 35 and 45 DAS, $\mathrm{W}_{3}=$ BRRI weeder at 30 and 45 DAS, $\mathrm{W}_{4}=$ No weeding, BCR= Benefit Cost Ratio. 


\section{REFERENCES}

Al-Mamun, M A, R Shultana, M A B Siddique, M S Zahan, S Pramanik. 2010. Impact of oxadiazon and pyrazosulfuron ethyl on rice and associated weeds in dry season rice cultivation. Pak. J. Weed Sci. Res. 16 (3): 309-319.

Burgos, N R, R J Norman, D R Gealy and H Black. 2006. Competitive $\mathrm{N}$ uptake between rice and weedy rice. Field Crops Res. 99: 96-105.

Chauhan, B S and D E Johnson. 2010a. Relative importance of shoot and root competition in dryseeded rice growing with jungle rice (Echinochloa colona) and ludwigia (Ludwigia hyssopifolia). Weed Sci. 58: 295-299.

Chauhan, B S and D E Johnson. 2011a. Competitive interactions between weedy rice and cultivated rice as a function of added nitrogen and the level of competition.Weed Biol. Manage. 11: 202-209.

Chauhan, B S and J Ope rna. 2013. Weed management and grain yield of rice sown at low seeding rates in mechanized dry-seeded systems Field Crops Research 141: 9-15.

Gomez, K A and A A Gomez. 1984. Statistical Procedures for Agricultural Research, 2nd Ed., John Wiley and Sons Inc., New York.

Janiya, J D and K Moody. 1989. Weed populations in transplanted and wet-seeded rice as affected by weed control method. Tropical Pest Management, 35(1): 8-11.

Johnson, D E. 1996. Weed management in small holder rice production in the tropics. Available at http:/ /ipmworld.umn.

edu/chapters/johnson.htm. Accessed on 7 Aug 2009.

Kamara A Y, F Ekeleme, L O Omoigui and D Chikoye. 2011. Influence of nitrogen fertilization on yield and yield components of rainfed lowland NERICA $₫$ rice in the northern Guinea savanna of Nigeria. African J. Agric. Res. 6(13): 3092-3097.

Khaliq, A, A Matloob, N Ahmad, F Rasul and I U Awan. 2012. Post emergence herbicide application appeared to be a viable strategy for weed control in direct seeded rice with higher economic returns. J. Anim. Plant Sci. 22(4)

Mortimer, A M and C R Riches. 2001. Current status and future trends in grass weed occurrence and control worldwide. In: Proceedings of the International Symposium on The World's Worst Weeds, Hilton, Brighton, UK, 12 November 2001, pp. 21-40.

Oikeh, S O, F Nwilene, S Diatta, S Osiname, O Touré and K A Okeleye. 2008. Responses of upland NERICA rice to nitrogen and phosphorus in forest agroecosystem. Agronomy J., 100: 735-741.
Rana, S S, N N Angiras and G D Sharma. 2000. Effect of herbicides and intercultural on nutrient uptake by puddle seeded rice and associated weeds. Indian J. Weed Sci., 32:70-73.

Roder, W and B Keobulapha. 1997. Weeds in slash-andburn rice fields in northern Laos. Weed Res. 37:111-119.

Rao, A N. 1985. Weed vegetation analysis. Lecture presented to participants attending the Weed Science Workshop, July-September 1985, IRRI, and Los Baños, Philippines.

Rao, A N, D E Johnson, B Sivaprasad, J K Ladha and A M Mortimer. 2007. Weed management in direct seeded rice. Adv. Agron. 93: 153-255.

Russell, D F. 1986. MSTAT-C computer based data analysis software. Crop and Soil Science Department, Michigan State University, USA.

Shultana, R, M A A Mamun, S A Rezvi and M S Zahan. 2011. Performance of some pre emergence herbicides against weeds in winter rice. Pak. J. Weed Sci. Res. 17(4): 365-372.

Singh and Prasad. 1999. Response of promising spring sown rice ( Oryza sativa L.) to sowing time, $\mathrm{N}$ levels under upland situation. Ann. Agric. Res. 20 (3): 296-300.

Singh, S, J K Ladha, R K Gupta, L Bhushan and A N Rao. 2008. Weed management in aerobic rice systems under varying establishment methods. Crops protect. 27: 660-671.

Smith, R J. 1992. Biological controls as components of integrated weed management for rice in the U.S. In: Proceedings of the International Symposium on Biological Control and Integrated Management of Paddy and Aquatic Weeds inAsia. Sukuba, Japan, pp. 335-351.

Sunil, C M, B G Shekara, K N Kalyanmurthy and B C Shankaralingapa. 2010. Growth and yield of aerobic rice as influenced by integrated weed management practices. Ind. J. Weed Sci. 42(3\&4):180-183.

Uddin, S, M A R Sarkar, M M Rahman. 2013. Effect of nitrogen and potassium on yield of dry direct seeded rice cv. NERICA 1 in Aus season. Intl. J. Agron. Plant. Prod. 4 (1): 69-75.

Thi, H L, L H Man, D V Chin, B A Auld, S D Hetherington. 1999. Research on some fungi to control barnyard grass and red sprangletop in rice. In: Proceedings of the 17th Asian-pacific Weed Science Society conference, Bangkok, Thailand. P. 562-566. 